\title{
Biotic and Abiotic Stress-Induced Phenylpropanoids in Leaves of the Mango (Mangifera indica L., Anacardiaceae)
}

\author{
Rodolfo R. da Silva, ${ }^{a}$ Cláudio A. G. da Câmara, ${ }^{a}$ Argus V. Almeida ${ }^{b}$ and \\ Clécio S. Ramos*,a
}

\author{
${ }^{a}$ Departamento de Química and ${ }^{b}$ Departamento de Biologia, Universidade Federal Rural de \\ Pernambuco, Rua Dom Manoel de Medeiros, s/n, 52.171-030 Recife-PE, Brazil
}

\begin{abstract}
A composição química de plantas é afetada por estresses abióticos e bióticos. No caso da Mangifera indica foi observado que as suas folhas respondem claramente a ataque do gafanhoto Tropidacris collaris e por dano causado mecanicamente, biossintetizando diversos compostos voláteis associados aos estresses, principalmente fenilpropanóides como miristicina, dilapiol, eugenol e acetato de eugenol. A identificação desses fenilpropanóides em folhas de mangueira como resposta aos estresses abióticos e bióticos é crucial à pesquisa de novos pesticidas naturais, considerando que fenilpropanóides possuem diversas atividades biológicas, principalmente inseticidas.
\end{abstract}

It is now widely recognized that plant's chemical composition is affected by both abiotic and biotic stress. This is the case of Mangifera indica leaves which respond very clearly to the damages caused by the grasshopper Tropidacris collaris and to mechanical damage by biosynthesizing several stress-related volatile compounds, mainly phenylpropanoids such as myristicin, dillapiole, eugenol and eugenol acetate. The identification of these phenylpropanoids in mango leaves in response to abiotic and biotic stress factors is a key step in the search for new natural pesticides, since phenylpropanoids have various biological activities, mainly insecticidal.

Keywords: Mangifera indica, biotic stress, abiotic stress, phenylpropanoids, Tropidacris collaris

\section{Introduction}

It is now widely recognized that a plant's chemical composition is affected by abiotic stress, as well as biotic stresses like herbivory. ${ }^{1}$ Thus, plants biosynthesize a wide spectrum of secondary metabolites when they are injured by herbivores, mainly phenylpropanoids and their derivatives. ${ }^{2,3}$

Phenylpropanoid encompass a wide range of structural classes with diverse biological activities. They are derived from cinnamic acid, which is formed from phenylalanine by the action of phenylalanine ammonia-liase (PAL). ${ }^{3}$

The activation of PAL in plants is increased by abiotic and biotic stresses, such as ozone exposure, low nutrient levels, pathogen attacks (i.e., fungal, bacterial, and viral) and herbivore attack. For example, in response to attack of larvae of the wheat midge Sitodiplosis mosellana, wheat

*e-mail: clecio@dcm.ufrpe.br seeds increase the production levels of $p$-coumaric and ferulic acids. ${ }^{4}$ para-Coumaric, trans-ferulic, and cis-ferulic acids also have been found in corn as resistance to attack of the corn borer Sesamia nonagrioides. ${ }^{5}$

In Arabidopsis thaliana (Brassicaceae) exposed to ozone during $3 \mathrm{~h}$ its level of PAL mRNA was induced three times higher when compared with the control plant. ${ }^{6}$ Crabapple leaves (Malus spp. - Rosaceae) that had been damaged overnight by Japanese beetles (Popillia japonica Scarabeidae) produced a complex mixture of aliphatic compounds, phenylpropanoid-derived compounds, and terpenoids. ${ }^{7}$ In another study, wounding and ethylene caused changes in the phenylpropanoid content of lettuce (Lactuca sativa - Asteraceae). ${ }^{8}$ Thus, there is no doubt that a wide variety of secondary metabolites in plants are induced by various abiotic and biotic stress factors.

In the present study, the induced response of phenylpropanoid compounds and their derivatives was investigated when Mangifera indica is attacked 
by the grasshopper Tropidacris collaris (Acridoidea Romaleidae), and this induced response is compared to inflicted by artificial damage.

The grasshopper, T. collaris, sometimes known as the violet-winged or giant grasshopper, is a large colorful insect, often encountered in South America from Colombia to central Argentina. ${ }^{9}$ It can be found in a diversity of habitats, from humid forests to dry or semiarid open areas. Nymphs are gregarious and form dense aggregations close to the ground on small shrubs. Mature insects are solitary and they disperse usually to diverse vegetation types, including mango, coconut, avocado, banana, cotton, lemon and rubber crops causing serious damage. ${ }^{10}$

We have observed that $M$. indica leaves infested with the grasshopper T. collaris emit phenylpropanoids as a response to biotic stress as well as abiotic stress caused by mechanical damage. So far, no previous studies have been published regarding the production of mango leaf volatiles induced by abiotic and biotic stresses. Moreover, the present investigation can reveal which compounds have a role of chemical defense for a commercially valuable tree.

\section{Experimental}

Plant material

Healthy, pest-free, adult $M$. indica stems with leaves were removed from mango trees $(\mathrm{N}=3)$ growing next to the entomology laboratory of Federal Rural University of Pernambuco and maintained for $24 \mathrm{~h}$ in pots with water in a greenhouse without supplementary lighting. Removed leaves ( 3 pots) were infested with grasshoppers (15 male and female individuals to a pot) to simulate biotic stress for $4 \mathrm{~h}$. Mechanical damage was caused by piercing leaf tissues (3 pots) with a paper punch to simulate abiotic stress for $4 \mathrm{~h}$. Nine $80 \mathrm{~mm}$ holes were punched in each leaf. Three pots with removed undamaged leaves were used as controls. All leaves were collected at the same time and were then frozen until chemical analysis was carried out.

Insects

The adult grasshoppers were collected in the city of Pombo, Pernambuco (semi-arid northeastern Brazil) and identified by Dr. Argus Vasconcelos de Almeida (Department of Biology, Federal Rural University of Pernambuco). The grasshoppers were reared in cages in the University's Entomology Laboratory (Department of Biology), maintained on a diet of $M$. indica leaves for several generations under an artificial light regime $(17 \mathrm{~h}$ light-7 h dark) at a temperature of $30 \pm 2{ }^{\circ} \mathrm{C}$ and relative humidity of $72 \pm 10 \%$. Voucher specimens of $T$. collaris have been deposited in the same laboratory, which contains a grasshopper collection.

\section{Chemicals}

Eugenol, $E$-caryophyllene, $\alpha$-humulene, eugenol acetate, $E$-nerolidol, dillapiole and caryophyllene oxide were purchased from Aldrich. Myristicin was isolated from Piper solmsianum (Piperaceae).

\section{Essential oil extraction}

Fresh plants were submitted to hydrodistillation in a clevenger-type apparatus consisting of a $500 \mathrm{~mL}$ distillation bottle, a $5 \mathrm{~mL}$ graduated receiver, and a jacketed-coil condenser. A total of $100 \mathrm{~g}$ of dried plant material and $250 \mathrm{~mL}$ of $\mathrm{H}_{2} \mathrm{O}$ were used, and the distillation was carried out for $4 \mathrm{~h}$ after the mixture had reached boiling. Condensation of the steam followed by accumulation of the essential oil/water system in the graduated receiver resulted in separation of the essential oil from the water, allowing further manual collection of the organic phase. Traces of water were removed by freezing the sample below $0{ }^{\circ} \mathrm{C}$ followed by transferring unfrozen essential oil to a new vial to yield yellowish volatile oils. The samples were kept in a freezer until further analysis. Yields were calculated from the weight of the dried material.

\section{Essential oil analysis}

The essential oils obtained by hydrodistillation were analyzed by GC-MS in a Shimadzu QP5050A system (Shimadzu Corporation, Kyoto, Japan) equipped with an AOC-20i autosampler under the following conditions: J\&W Scientific DB-5MS fused silica capillary column $(30 \mathrm{~cm} \times 0.25 \mathrm{~mm}$ i.d.) and capillary VF-WAXms column $(30 \mathrm{~m} \times 0.25 \mathrm{~mm}$ i.d. $\times 0.25 \mu \mathrm{m})$ from Varian, operating in electron impact mode at $70 \mathrm{eV}$. Helium as the carrier gas at a constant flow of $1.2 \mathrm{~mL} \mathrm{~min}^{-1}$. The injection volume was $0.5 \mu \mathrm{L}$ (split ratio of 1:100), the injector temperature was $250^{\circ} \mathrm{C}$ and the ion-source temperature was $280^{\circ} \mathrm{C}$. The oven temperature was programmed from $50{ }^{\circ} \mathrm{C}$ (isothermal for $2 \mathrm{~min}$ ), with an increase of $4{ }^{\circ} \mathrm{C}$ per min to $200{ }^{\circ} \mathrm{C}$, then $10{ }^{\circ} \mathrm{C}$ per min to $300{ }^{\circ} \mathrm{C}$, ending with a $10 \mathrm{~min}$ isothermal at $300{ }^{\circ} \mathrm{C}$. Mass spectra were taken at $70 \mathrm{eV}$ with a scan interval of $0.5 \mathrm{~s}$ and fragments from 40 to $550 \mathrm{Da}$. Quantitative analysis of the chemical constituents was performed by flame ionization gas chromatography (FID), using a Shimadzu GC-17A instrument (Shimadzu Corporation, Kyoto, Japan), under the following operational 
conditions: capillary ZB-5MS column (5\%-phenylarylene - 95\%-dimethylpolysiloxane) fused silica capillary column $(30 \mathrm{~m} \times 0.25 \mathrm{~mm}$ i.d. $\times 0.25 \mu \mathrm{m}$ film thickness $)$ from Phenomenex (Torrance, CA, USA), under the same conditions as reported for the GC-MS. Quantification of each constituent was estimated by area normalization (\%). Compound concentrations were calculated from the GC peak areas and were arranged in order of GC elution. Identification of individual components of the essential oil was performed by computerized matching of the acquired mass spectra with those stored in the NIST21 and NIST107 mass spectral libraries of the GC-MS data system and by comparison of their retention times with those of authentic standards. Retention indices (RI) for all compounds were determined according to Vandendool and Kratz for each constituent as previously described. ${ }^{10-13}$

\section{Results and Discussion}

The essential oil from the undamaged $M$. indica leaves obtained by hydrodistillation and analyzed via combined GC-FID and GC-MS contained 17 known compounds, making up $72.0 \%$ of the total composition. The main compound was diterpene labd-7.13-dien-15-ol, accounting for $26.8 \%$, but the predominant class was sesquiterpenes $(46.8 \%)$. The main sesquiterpenes identified were gymnomitrone (24.9\%), 14-hydroxy-4,5-dihydro caryophyllene $(9.3 \%)$ and caryophyllene oxide $(1.2 \%)$ (Table 1). Previous studies of the essential oil of mango leaves, from various regions such as Brazil, Nigeria, China and Colombian, have shown that the main compound classes were sesquiterpenes (e.g., $\beta$-caryophyllene, caryophyllene oxide, $\delta$-carene, $\alpha$-gurjunene, $\beta$-selinene, humulene epoxide) and monoterpenes (e.g., $\beta$-pinene, $\alpha$-pinene, limonene, myrcene, cis and trans-ocimene). ${ }^{14-18}$

GC-MS analysis of the essential oil from mango leaves infested with mature T. collaris grasshoppers and mechanically damaged indicated in both cases that the chemical profile of the oils changes dramatically compared to the oil from the intact leaves (Table 1, Figure 1). Mechanical damaged leaves emit relatively large amounts of phenylpropanoids, dillapiole and myristicin, accounting for 55.1 and $3.4 \%$ of the total composition, respectively. Neither dillapiole nor myristicin were found in the essential oil from intact leaves. The same result was observed in phytochemical studies of $M$. indica previously reported. ${ }^{14-18}$ Among the volatiles emitted by mechanically damaged leaves, caryophyllene oxide, E-nerolidol, globulol, humulene epoxide II, $\alpha$-cadinol, labd-7.13-dien-15-ol and gymnomitrone were found in the intact leaves as well (Table 1).
More than 20 compounds were identified in the essential oil from leaves infested with $T$. collaris grasshoppers, including phenylpropanoids eugenol and eugenol acetate. $E$-caryophyllene, caryophyllene oxide, spathullenol, humulene epoxide II, ledol, labd-7.13-dien-15-ol and gymnomitrone were also found in the intact leaves (Table 1, Figure 1). Oleic acid was the main constituent of the leaves infested with grasshoppers (27.9\%), followed by sesquiterpene amorphene and phenylpropanoid eugenol, accounting for 10.8 and $9.1 \%$ of the total composition, respectively.

The results of our experiment demonstrate that $M$. indica leaves respond very clearly to grasshopper infestation and mechanical damage, by biosynthesizing several stressrelated volatile compounds, mainly phenylpropanoids such as myristicin, dillapiole, eugenol and eugenol acetate. The presence of myristicin, dillapiole and eugenol in mango leaves due to induced chemical response to abiotic and biotic stress factors has a significant ecological role in plant-animal interactions. Myristicin has a functional group characteristic of inhibitors of pivotal detoxification enzymes (cytochome P450) and it synergizes the toxicity of xanthotoxin, a furanocoumarin found in umbelliferous plants, to the generalist caterpillar Helicoverpa zea almost five-fold. ${ }^{19}$ Dillapiole was observed to synergize the insecticidal action of cypermethrin and lambdacyhalothrin against Spodoptera litura. ${ }^{20}$ Just as myristicin and dillapiole, eugenol has insecticidal properties showing high toxicity against beetles Sitophilus granarius, Sitophilus zeamais, Tribolium castaneum and Prostephanus truncatus. ${ }^{21}$

Despite previously reported insecticidal activity myristicin and dillapiole, these two phenylpropanoids were only detected in mango leaves with abiotic stress. This fact can be associated to the ability of a plant to respond differently to different types of wounding and to different insect species. ${ }^{1}$

The major compounds of mango clean leaves labd7.13-dien-15-ol and gymnomitrone were reduced to trace amount $(<0.1 \%)$ following plant exposure to stresses. This significant decrease in mango leaves is still unclear. Induced defenses imply that chemical profiles of a determined plant can be altered in response to diverse stress conditions. In leaves from the hybrid willow clone (Salix burjatica $\times S$. dasyclados), the amount of isoprene deeply decreases when the plant is infected by the fungus Melampsora epitea. ${ }^{22}$ The isoprene reduction in willow leaves can be related to the drain out of carbohydrates from the plant cells by fungus. In the case of mango leaves, a possible explanation for labd-7.13-dien-15-ol and gymnomitrone reductions is that these compounds can be used by the plant in the synthesis of some stress-induced volatiles. 
Table 1. Volatile compounds identified in the essential oils from the intact leaves, grasshopper-infested leaves (biotic stress) and mechanically damaged leaves (abiotic stress)

\begin{tabular}{|c|c|c|c|c|c|c|c|c|}
\hline \multirow[t]{3}{*}{ Compounds $^{\mathrm{a}}$} & \multicolumn{2}{|c|}{ RI } & \multicolumn{6}{|c|}{ Composition on leaves / \% } \\
\hline & \multirow[t]{2}{*}{$\mathrm{RI}^{\mathrm{b}}$} & \multirow[t]{2}{*}{$\mathrm{RI}^{\mathrm{c}}$} & \multicolumn{2}{|c|}{ Intact } & \multicolumn{2}{|c|}{ Abiotic stress } & \multicolumn{2}{|c|}{ Biotic stress } \\
\hline & & & $\%$ & $\mu \mathrm{g} \mathrm{mg}^{-1}$ & $\%$ & $\mu \mathrm{g} \mathrm{mg}^{-1}$ & $\%$ & $\mu \mathrm{g} \mathrm{mg}^{-1}$ \\
\hline Hexenol & 863 & 1356 & 0.3 & 3.2 & & & & \\
\hline$p$-Cymene & 1089 & 1284 & & & & & 0.1 & 1.1 \\
\hline Terpinem-4-ol & 1174 & 1625 & & & & & 3.9 & 41.8 \\
\hline p-Cymen-9-ol & 1204 & 1538 & & & & & 0.3 & 3.2 \\
\hline Eugenol $^{\mathrm{d}}$ & 1356 & 2014 & & & & & 9.1 & 97.5 \\
\hline$(E)$ - $\beta$-Elemene & 1389 & 1621 & & & & & 0.6 & 6.4 \\
\hline$\alpha$-Gurjunene & 1409 & 1598 & & & & & 2.0 & 21.4 \\
\hline E-Caryophyllene ${ }^{\mathrm{d}}$ & 1417 & 1601 & 0.3 & 3.2 & 0.2 & 1.9 & 1.9 & 20.4 \\
\hline (E)- $\alpha$-Ionone & 1428 & 1821 & & & 0.2 & 1.9 & & \\
\hline$\alpha$-Humulene ${ }^{\mathrm{d}}$ & 1452 & 1645 & & & & & 0.6 & 6.4 \\
\hline (E)- $\beta$-Ionene & 1487 & 1785 & & & 0.5 & 4.8 & & \\
\hline epi-Cubenol & 1493 & 2039 & & & 0.3 & 2.9 & & \\
\hline Amorphene & 1495 & 1699 & & & & & 11.0 & 117.9 \\
\hline Viridiflorene & 1496 & 1701 & & & & & 1.5 & 16.1 \\
\hline n-Pentadecane & 1500 & 1509 & & & 0.4 & 3.8 & & \\
\hline Myristicin $^{\mathrm{d}}$ & 1517 & 1939 & & & 3.4 & 32.4 & & \\
\hline Eugenol acetate $^{d}$ & 1521 & 1805 & & & & & 5.0 & 53.6 \\
\hline Zonarene & 1528 & 1792 & & & 0.4 & 3.8 & & \\
\hline$\alpha$-Calacorene & 1544 & 2208 & 0.4 & 4.3 & & & & \\
\hline Elemol & 1548 & 2089 & & 0.0 & & & 1.1 & 11.8 \\
\hline$E$-Nerolidol ${ }^{\mathrm{d}}$ & 1561 & 2020 & 0.7 & 7.5 & 16.7 & 159.0 & & \\
\hline 3Z-Hexenyl benzoate & 1565 & 1715 & & & & & 0.3 & 3.2 \\
\hline Spathullenol & 1577 & 2085 & 0.1 & 1.1 & & & 0.5 & 5.4 \\
\hline Caryophyllene oxide $^{\mathrm{d}}$ & 1582 & 2019 & 1.2 & 12.9 & 0.6 & 5.7 & 0.3 & 3.2 \\
\hline Globulol & 1590 & 2080 & 0.6 & 5.9 & 0.5 & 4.4 & & \\
\hline Viridiflorol & 1593 & 2101 & 0.6 & 6.1 & & & & \\
\hline Ledol & 1602 & 2032 & 0.6 & 6.4 & & & 0.3 & 3.2 \\
\hline Humulene epoxide II & 1608 & 2025 & 1.1 & 11.8 & 0.3 & 2.9 & 0.3 & 3.2 \\
\hline Dillapiole $^{\mathrm{d}}$ & 1620 & 1962 & & & 55.3 & 523.8 & & \\
\hline Muurola-4.10(14)-dien-1- $\beta$-ol & 1630 & 2149 & 1.7 & 18.2 & & & & \\
\hline Gymnomitrone & 1631 & 1855 & 24.9 & 266.8 & 0.08 & 0.8 & 0.07 & 0.8 \\
\hline Cubenol & 1645 & 1999 & 1.0 & 10.7 & & & & \\
\hline Cedr-8(15)-em-9- $\alpha$-ol & 1650 & 2118 & & & & & 0.8 & 8.6 \\
\hline$\alpha$-Cadinol & 1652 & 2194 & 1.7 & 18.2 & 0.3 & 2.9 & & \\
\hline trans-Calamen-10-ol & 1668 & 2335 & 0.7 & 7.5 & & & & \\
\hline Mustakone & 1676 & 2365 & 0.4 & 4.3 & & & & \\
\hline Caryophyllene $<14$-hydroxy-4.5-dihydro $>$ & 1706 & 2379 & 9.3 & 99.6 & & & 0.01 & 0.1 \\
\hline Benzyl benzoate & 1759 & 2072 & & & & & 3.8 & 40.7 \\
\hline Hexadecanoic acid & 1959 & 2861 & & & & & 4.0 & 42.3 \\
\hline Ethyl hexadecanoate & 1993 & 2251 & & & & & 4.0 & 42.9 \\
\hline Oleic acid & 2141 & 2432 & & & & & 28.0 & 300.0 \\
\hline Ethyl octadecanoate & 2196 & 2446 & & & & & 2.0 & 21.4 \\
\hline Labd-7.13-dien-15-ol & 2291 & 2592 & 26.8 & 287.1 & 0.06 & 0.6 & 0.07 & 0.8 \\
\hline TOTAL $^{\mathrm{e}}$ & & & 72.4 & & 78.9 & & 81.6 & \\
\hline
\end{tabular}

${ }^{\mathrm{a}}$ Compounds are listed in order of their elution from an DB-5MS column. Retention indices as determined on non-polar DB-5MS ${ }^{\mathrm{b}}$ and polar VF-WAXms ${ }^{\mathrm{c}}$ columns using the homologous series of $n$-alkanes. ${ }^{\mathrm{d}}$ Method of identification by injection of an authentic sample. ${ }^{\mathrm{e}}$ Total percentage of compounds identified (retention indices of compounds unknown were not added in the table). 


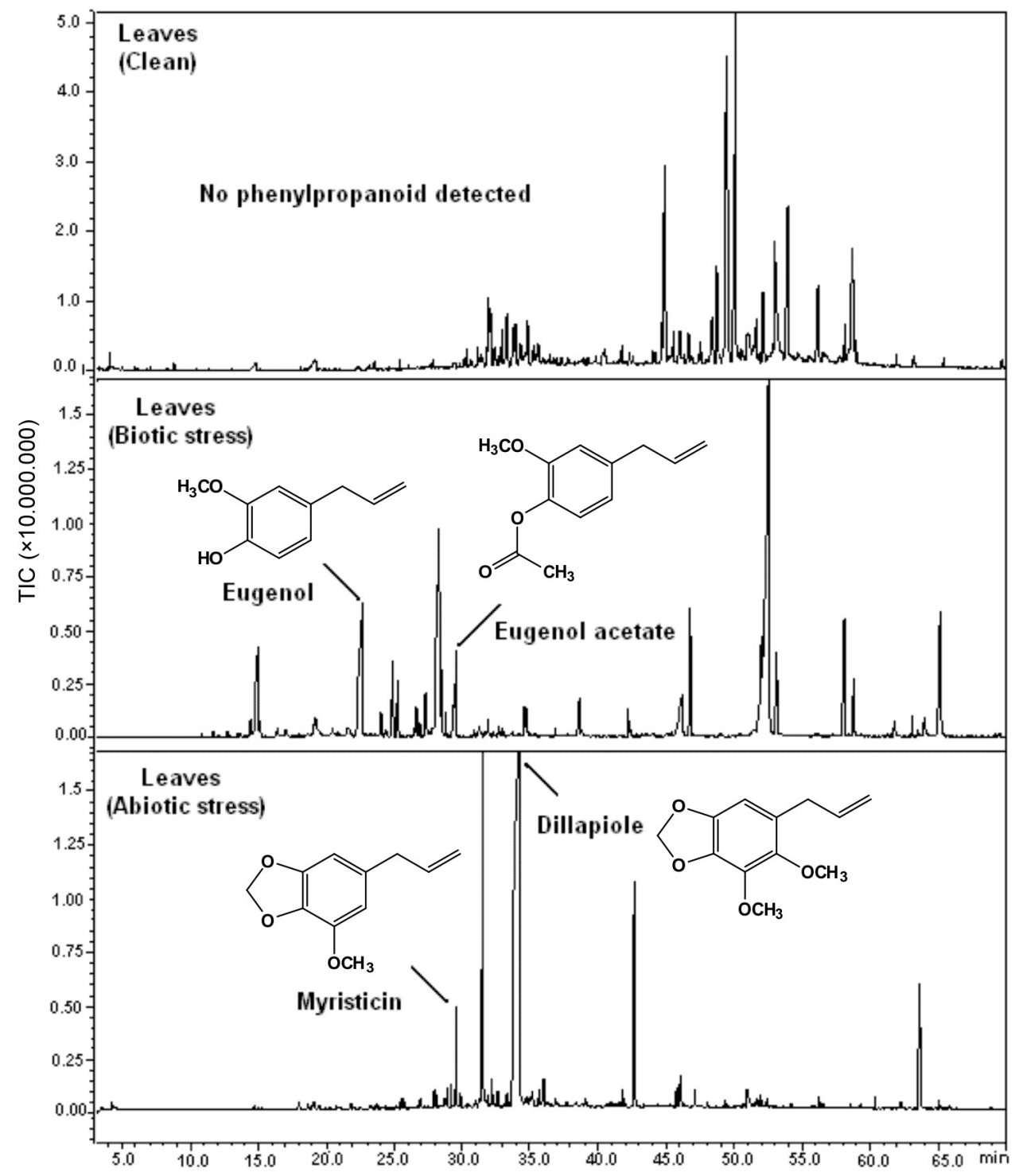

Figure 1. Chemical profiles (GC-MS) of essential oils of $M$. indica leaves: intact leaves, leaves infested with grasshoppers and mechanically damaged leaves.

\section{Conclusions}

In summary, all the samples of $M$. indica leaves under stress conditions showed significant relative percentages of phenylpropanoids, due more to abiotic stress (58.7\%) than to infestation by grasshoppers (14.1\%). Phenylpropanoids were not identified in undamaged $M$. indica leaves, indicating that their presence express an induced resistance mechanism in response to abiotic and biotic stresses. The elucidation of the induced chemical defense to stress in $M$. indica here reported is also relevant from ecological and agricultural perspective, since the change of the chemical profile can significantly affect the aroma and flavor of mango fruit, reducing its commercial value. Moreover, stress-induced plant compounds that have been selected by evolution to interact with potential enemies, such as bacteria, viruses, fungi, nematodes, mites, insects, mammals and other herbivorous animals, are promising agents for the development of new natural pesticides.

\section{Acknowledgments}

This work was funded by grants provided by FACEPE. R. R. S. thanks CNPq for providing a scholarship. The authors are indebted to the Centro de Apoio a Pesquisa (CENAPESQ), UFRPE, for the laboratory facilities.

\section{References}

1. Schoonhoven, M. L.; Van Loon, J. J. A.; Dicke, M.; Insect-Plant Biology, $2^{\text {th }}$ ed.; Oxford: New York, 2005.

2. Karban, R.; Baldwin, I. T.; Trends Ecol. Evol. 1998, 13, 83. 
3. Dixon, R. A.; Paiva, N. L.; Plant Cell 1995, 7, 1085.

4. Ding, H.; Lamb, R. J.; Ames, N.; J. Chem. Ecol. 2000, 26, 969.

5. Santiago, R.; Butroän, A.; Reid, L. M.; Arnason, J. T.; Sandoya, G.; Souto, X. C.; Malvar, R. A.; J. Agric. Food Chem. 2006, 54, 9140.

6. Iriti, M.; Faoro, F.; Int. J. Mol. Sci. 2009, 10, 3371.

7. Loughrin, J. H.; Potter, D. A.; Hamilton-Kemp, T. R.; J. Chem. Ecol. 1995, 10, 1457.

8. Loaiza-Velarde, J. G.; Tomas-Barbera, F. A.; Saltveit, M. E.; J. Am. Soc. Hort. Sci. 1997, 122, 873.

9. Attard, L. M.; Carreno, R. A.; Paré, J. A.; Peregrine, A. S.; Dutton, C. J.; Mason, T. R.; J. Zoo Wildl. Med. 2008, 39, 488.

10. Santos, F. D.; Veiga, A. F. S. L.; Santos, F. A. B.; Torres, J. B.; Teixeira, A. A. C.; Valeria, W. T.; Neotrop. Entomol. 2007, 36, 396.

11. Van den dool, H.; Kratz, P. D.; J. Chromatogr. 1963, 11, 463.

12. Adams, R. P.; Identification of Essential Oil Components by Gas Chromatography/Mass Spectroscopy, $4^{\text {th }}$ ed.; Allured Publishing Corporation: Illinois, 2007.

13. Marquesa, F. A.; McElfresh, J. S.; Millara, J. G.; J. Braz. Chem. Soc. 2000, 6, 592.
14. Moreno, A.; Leon, D. F.; Giraldo, G. A.; Rios, E.; Rev. Colomb. Quim. 2010, 39, 61.

15. Dzamic, A. M.; Marin, P. D.; Gbolade, A. A.; Ristic, M. S.; J. Essent. Oil Res. 2010, 22, 123.

16. Pino, J. A.; Mesa, J.; Muñoz, Y.; Marti, M. P.; Marbot, R.; J. Agric. Food Chem. 2005, 53, 2213.

17. Ansari, S. H.; Ali, M.; Neguruela, A. V.; J. Med. Aromat. Plant Sci. 2000, 22, 582.

18. Berenbaum, M.; Neal, J. J.; J. Chem. Ecol. 1985, 11, 1349.

19. Núñez-Sellés, A. J.; J. Braz. Chem. Soc. 2005, 4, 699.

20. Shankarganesh, K.; Subrahmanyam, B.; Walia, S.; Dhingra, S.; Pest Res. J. 2009, 21, 143.

21. Obeng-Ofori, D.; Reichmuth, Ch.; Int. J. Pest. Manag. 1997, 43,89 .

22. Toome, M.; Randjärv, P.; Copolovici, L.; Niinemets, U.; Heinsoo, K.; Luik, A.; Noe, S. M.; Planta 2010, 232, 235.

Submitted: August 2, 2011 Published online: November 17, 2011 